\title{
Adopting Roman Habits The Baths in the House of Orpheus in Nea Paphos as a 'Troublesome' Case Study?
}

\author{
Monika Rekowska, Demetrios Michaelides, \\ Skevi Christodoulou, JaKub KaniszewsKi
}

\begin{abstract}
The House of Orpheus at Nea Paphos in Cyprus, a multiphase residential complex excavated a few decades ago, is the subject of an on-going study within the framework of a new project. Recently, the bath suite in the north-eastern part of the house was analysed in detail and this has led to a better understanding of the baths' layout and technology (such as the water management and heating system), features that confirm the adoption of the western/Italian model, while some of the details remained typical of the Eastern Mediterranean.
\end{abstract}

Keywords: Nea Paphos, Roman period Cyprus, House of Orpheus, baths, heating system, water management

Monika Rekowska, University of Warsaw, Warsaw; mrekowska@uw.edu; (D) 0000-0001-6672-1319

Demetrios Michaelides, University of Cyprus, Nicosia; d.michaelides@ucy.ac.cy; (D) 0000-0002-5320-7617

Skevi Christodoulou, independent researcher, Nicosia; skevi.christodoulou@yahoo.com

Jakub Kaniszewski, independent researcher, Warsaw; jkaniszewski@tlen.pl

In 'the Romanisation debate', ${ }^{1}$ the Roman bathing ritual is generally given a fundamental place as one of the Roman civilisation's greatest emblems. As a consequence, Roman baths identified by a hypocaust system and a more or less fixed sequence of rooms (caldarium, frigidarium, tepidarium etc.), and bathing understood as a social event, are an obvious point of reference when defining the typical Roman lifestyle. Public baths began to become a characteristic feature of the Roman city from the second century BCE and, over time, bathing installations took a prominent place in private residences too. Nevertheless, the study of public baths as a pan-Roman phenomenon focused mainly on

\footnotetext{
${ }^{1}$ On the term Romanisation and subtle nuances between globalisation - acculturation - and creolisation in studies on the dissemination of Roman culture, cf. Kelly 2013: 131-132 (with bibliography).
} 
the evolution of space. Hence the search for baths with typical and repetitive layouts, and disposition and shape of rooms. ${ }^{2}$ By contrast, private baths present a great variety of layouts and as such they are usually the subject of limited research, conducted locally, with regard to specific regions, cities or single residences. ${ }^{3}$ Although the baths in the western Roman provinces are relatively well known, this is not always the case in the Eastern Mediterranean. In this context, Cyprus, a 'backwater' in baths studies, is well worth a deeper investigation. ${ }^{4}$

\section{BATHS IN THE PRIVATE CONTEXT IN CYPRUS}

At first glance, it would appear that baths in Cyprus are a relatively rare phenomenon, yet this is probably a false impression resulting from the present state of research. Approximately half of the twenty-plus known thermal complexes (Hellenistic, Roman and early Byzantine) come from private contexts and are found within residences. ${ }^{5}$ Only a few of these are well enough preserved to be investigated in a more detailed way, and even then, their functioning cannot always be interpreted. There are Roman baths in Kourion, at the House of the Gladiators (third-fourth century) ${ }^{6}$ and the Building of Eustolios (fourth-seventh century), ${ }^{7}$ in Nea Paphos, at the 'Hellenistic' House ${ }^{8}$ and the Villa of Theseus (fourth century), ${ }^{9}$ and, of course, the House of Orpheus. ${ }^{10}$ Almost all of them are of rather modest size (usually from 100 to $300 \mathrm{~m}^{2}$, except for the baths in the Villa of Theseus with an area of $500 \mathrm{~m}^{2}$ ), and their circulation pattern corresponds to a row or angular arrangement, some

\footnotetext{
${ }^{2}$ In research on Roman bath typology, their distinction depends mainly on the circulation patterns rather than on the arrangement and shape of the rooms; cf. the important work of Krencker, Krüger 1929 and Fagan 2001. Nevertheless, if the typical public baths are defined by 'gradation of heat in a clear sequence of rooms' (Fagan 1999: 403-404), in private, mostly asymmetrical installations the rules were applied with more flexibility. Private baths are only briefly discussed in the fundamental studies on the origins and development of Roman baths and bathing (Nielsen 1990; Yegül 1992; 2010).

${ }^{3}$ Cf. Uytterhoeven 2011 and the literature cited on p. 288, nn. 9-11; more recently: Maréchal 2020.

${ }^{4}$ The most comprehensive work is the $\mathrm{PhD}$ thesis on baths and bathing in Cyprus by Skevi Christodoulou under the supervision of Demetrios Michaelides, of which only a summary is published; cf. Christodoulou 2014a; 2014b. The real problem in discussing private baths in Cyprus is the lack of sufficient data due to the limited number of excavated and published houses.

${ }^{5}$ To the bathing complexes catalogued by Christodoulou, both public and private, one more private bath should be added, from the 'Hellenistic' House (south-western rooms) in Nea Paphos, that has been found since the completion of her $\mathrm{PhD}$.

${ }^{6}$ Christodoulou 2014a: 88-89; Christou 2007: 56-58; Kondoleon 1982: 103; Loulloupis 1971: 97, 103-105, 116; Nicolaou 1970a: 73-74; 1970b: 393; 1972: 314; 1973a: 58.

7 Christodoulou 2014a: 89-90; Christou 2007; Fales 1950: 30-35; Mitford 1971: 356-358, no. 204; Rupp 1982: 134.

${ }^{8}$ Meyza et al. 2014: 395-411.

${ }^{9}$ Christodoulou 2014a: 93-94; Daszewski 1970; 1972; 1976: 194-206; Karageorghis 1972: 1077-1078; Nicolaou 1973b: 430; 1975-1976: 65-66.

${ }^{10}$ Other private baths, in Kouklia (late second-early third century), Mansoura (third-fourth century), Alassa (fifth century) and perhaps Ayia Irini (late Hellenistic-early Roman period), as well as evidence of other baths, of unknown nature are listed in Christodoulou 2014a: 97-100, Table 1 (with bibliography).
} 
of them being accessible from both the interior and the exterior of the house. ${ }^{11}$ Undoubtedly, one of the best-preserved thermal complexes, uncovered in the Villa of Theseus in Nea Paphos, may constitute the closest comparison for the baths in the nearby House of Orpheus (despite the difference in chronology). ${ }^{12}$ These baths are in a worse state of preservation and their later repurposing (which resulted in the opening of new passages, the demolition of some structures, and the construction of new floors) raises problems in the understanding of their original layout. ${ }^{13}$ Moreover, fragments of painted plaster and loose tesserae do not allow us to draw more than very general conclusions about their decoration. Nevertheless, we can still try to reconstruct the bathing circulation pattern, and to point out some technical aspects of the baths' functioning, even if the identification of some features remains problematic.

\section{THE HOUSE OF ORPHEUS AND ITS REPRESENTATION WING}

The name House of Orpheus is used to describe a sequence of buildings within an insula in the Maloutena locality, the residential sector of Nea Paphos, yet the name of the building applies mainly to the phase of occupation of the late second and early third centuries $\mathrm{CE}^{14}$ This dating results from the study of the pottery and the stylistic analysis of the mosaic decoration, most probably commissioned by the then owner of the house. ${ }^{15}$ The mosaics as well as the location and the vastness of the richly decorated residence, the technology used within it, and the cost of maintenance and functioning of the whole complex were far beyond the reach of an ordinary man. Hence the house in question must have been the property of a member of the Paphian upper class.

The area was under systematic investigation from 1982 to1992 and later, even if not in a regular manner, until 2013. The study of the excavated material is continuing and, since 2018, non-invasive research is being carried out as part of a new project. ${ }^{16}$ Data acquired in the course of excavation, ${ }^{17}$ observations made during the survey, as well as the analysis of a 3D laser scan of the site allow us to distinguish several phases of occupation. The oldest corresponds to the original street grid dating back to the early Hellenistic

11 Christodoulou 2014a: 95.

12 Daszewski 1972: 222-224, Pls XXXIX.3, XL.5; 1976: 193-204, Pls XXXII.1-2, XXXIII.1, XXXIV.2-3.

13 These alterations could be very tentatively dated by the excavated finds to the middle of the third century CE or soon after; and they included a complete re-arrangement of the area of the praefurnium, which was blocked off and abandoned, and the partial dismantling (up to the level of the suspensura) of the wall between the caldarium and the tepidarium.

14 For localisation of the House of Orpheus, see e.g.: Romaniuk 2021: Fig. 1 in the present volume.

15 On the mosaics, cf. Michaelides 1986; 1987: 245; 1992; Michaelides, Daszewski 1988: 51-53; Nicolaou 1983.

16 On the project cf. Rekowska et al. 2019.

${ }^{17}$ Interim reports on the excavations were published regularly in the Annual Report of the Department of Antiquities in Cyprus (1983-1998) and the Bulletin de Correspondance Hellénique (1983-1993); a number of artifacts from the excavations were the subject of more detailed studies, all of which are listed in: Rekowska et al. 2019: 201, n. 16, and 215-218 (detailed bibliography of the House of Orpheus). 
period. ${ }^{18}$ The later phases relate to the Roman period, when Paphos continued to be the capital of the island. ${ }^{19}$ Although the chronology of the rebuilding cannot be established with certainty, it seems that there were important changes in the development of the entire area already in the early Roman period. ${ }^{20}$ Probably at this time, one larger house was built in the place of two smaller, earlier ones in the northern part of the excavated area, and, at the same time, the new residence was expanded to the south, incorporating a section of Street A between Units II and III, which was turned into a storage space (cf. Fig. 1). A modest bath complex was probably included into the existing buildings, along the eastern street.

At a later stage, these baths were expanded annexing additional space on the west, and their rebuilding should be linked with a substantial re-arrangement of the entire northern wing. As a result, this part took on a distinctly different character than that of the living area articulated around the peristyle to the south. Such a modification could be related to a new owner of the property, and it is tempting to see him as the person mentioned in the inscription: [ГӒ̈]O $\Sigma$ or [TIT] $\mathrm{O} \Sigma$ ПINNIO $\Sigma$ PE $\Sigma T I T O Y T O \Sigma$ EПOIEI written above the head of Orpheus in the mosaic from which the house took its name. ${ }^{21}$

The identification of the rooms results from the analysis of their plan and decoration. Nevertheless, this is not always possible and, inevitably, the present interpretation includes several uncertainties. ${ }^{22}$

In the western sector of the house (Fig. 2), one can see the sequence of reception rooms, notable for their elegant mosaics. One of the rooms, of a relatively large size, with a tripartite entry and a mosaic with two panels, one depicting an Amazon by her horse, the other Hercules fighting the lion of Nemea, can be defined as a triclinium (R 2). The neighbouring room (R 1 ) is smaller but adorned with a sophisticated mosaic with Orpheus and the beasts and the above-mentioned inscription. The room, having a more intimate character, could be interpreted as an oecus. On the opposite side of the corridor (R 4-5) there was a room (R 7) with an entry much larger than a simple doorway - this could serve as an exedra..$^{23}$ The eastern part was arranged as a bath suite.

Both parts - reception area on the west and baths area on the east - were interconnected, albeit with two independent entrances, by what seems to have been an open-air courtyard (R 6).

${ }^{18}$ For the plan of Nea Paphos, cf. Młynarczyk 1990: 162, Fig. 16; for an updated version, cf. Papuci-Władyka 2020: 83, Pl. 5. See also: Miszk, Ostrowski, Papuci-Władyka 2020, for a few additional remarks on the urban layout.

${ }^{19}$ Nea Paphos was already the island's capital by the late third/early second century BCE.

${ }^{20}$ It is impossible to know when exactly the whole area was re-organised. This may be linked to rebuilding activity following the earthquake of $15 \mathrm{BCE}$, when the whole city was badly damaged and then rebuilt during the Augustan period. However, one needs also to take into account the earthquake of 76/77 CE. On the chronology of the excavated remains, cf. Rekowska et al. 2019: 203-212; Rekowska et al. forthcoming.

${ }^{21}$ Although the inscription is written in Greek characters, the Latin tria nomina of the person mentioned as the 'maker', indicates that he is not the mosaicist but rather the person that commissioned the mosaic; see: Michaelides 1986: 485-486; SEG XXXVI, 36: 123bis; Donderer 1989: 73; Cayla 2018: 370.

${ }^{22}$ For the first attempt at layout interpretation, see: Christodoulou 2014a: 92-93, Figs 14-16; also: Rekowska et al. 2019; 2021.

${ }^{23}$ René Rebuffat defines such a sequence of triclinium-oecus-exedra as typical for reception rooms in Roman houses in North Africa (Rebuffat 1969: 662, n. 1). 


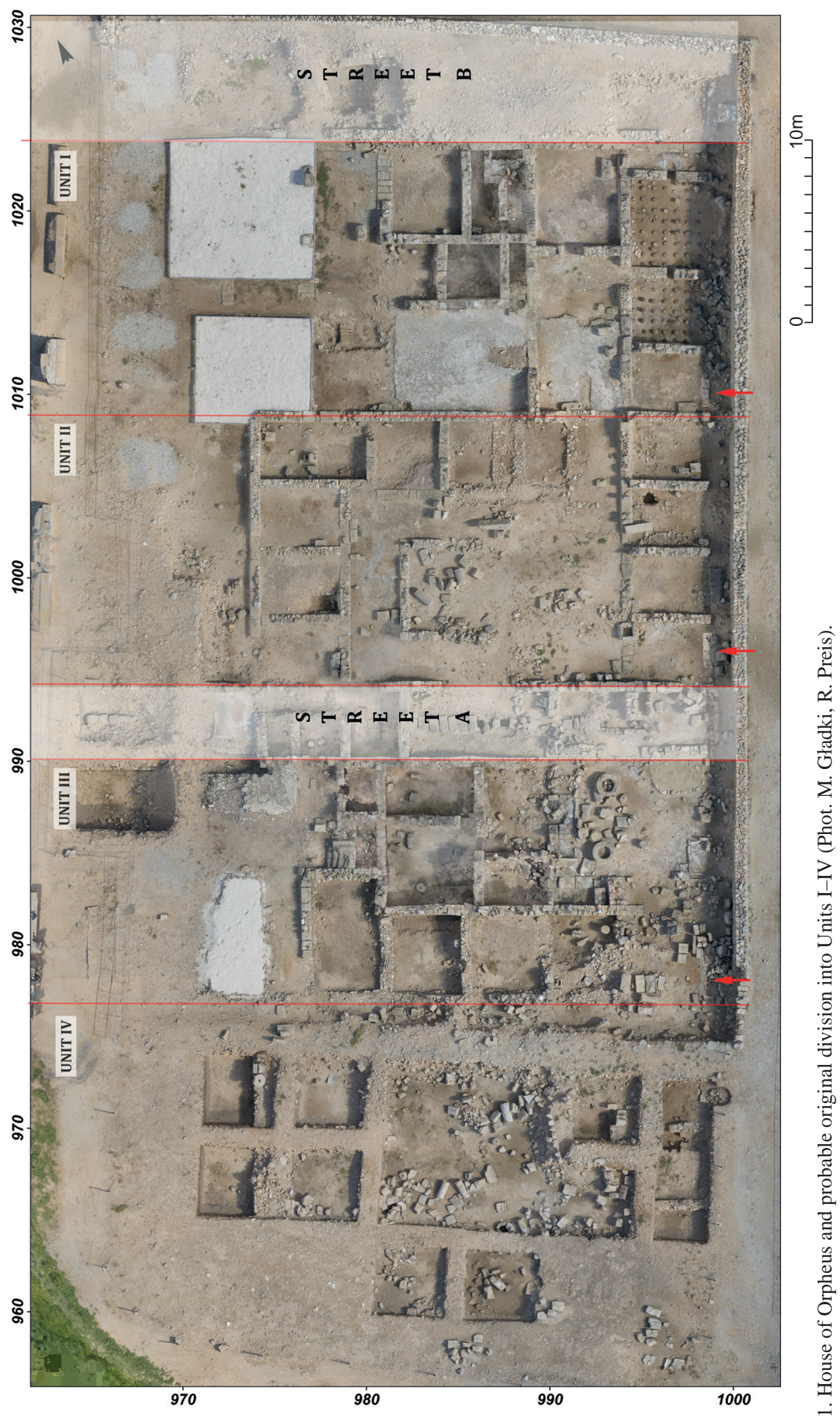




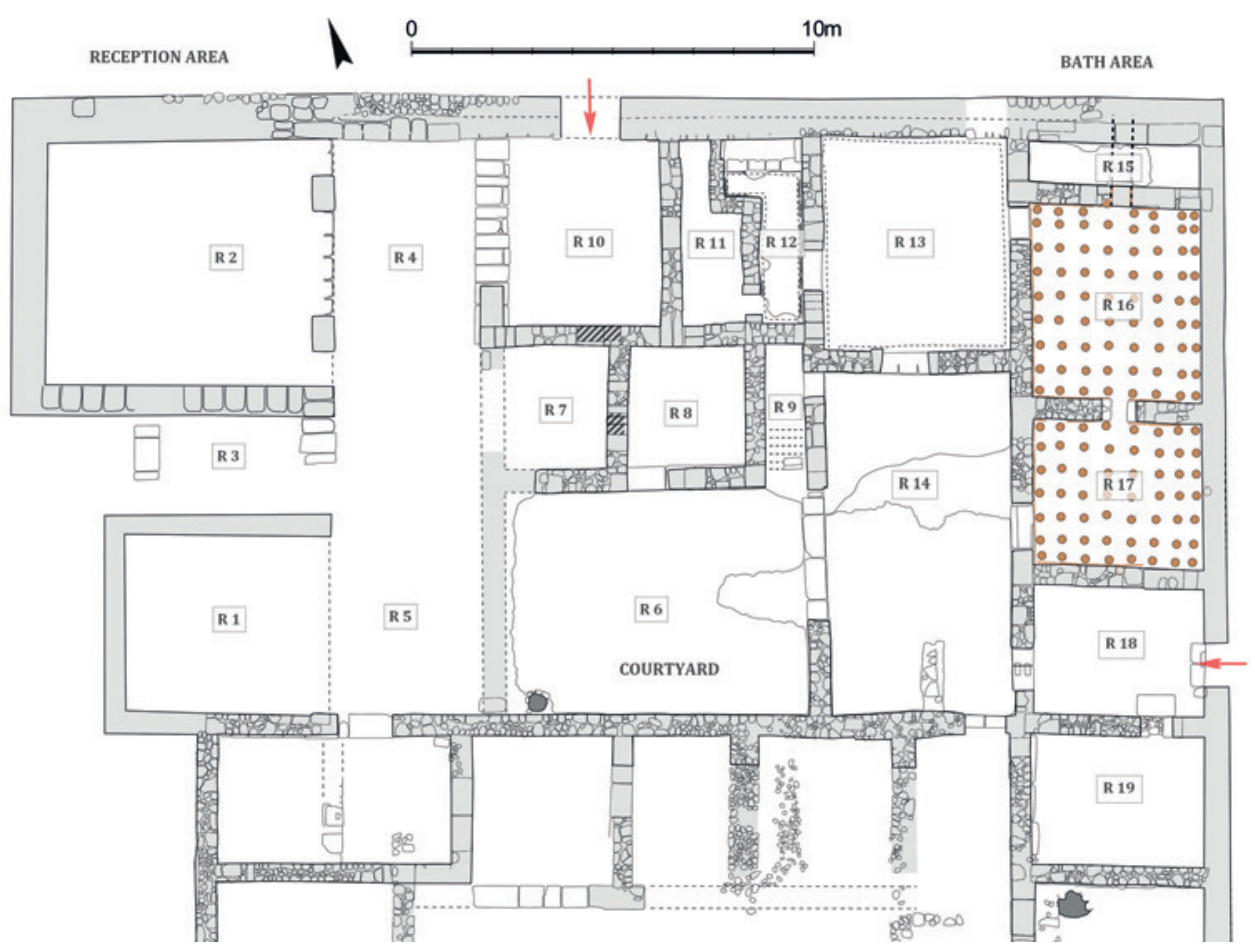

2. House of Orpheus, representation wing: reception and baths area (Drawing: J. Kaniszewski).

Such a complex, including the reception rooms on the one hand and baths on the other, allows the entire area to be interpreted as a representation wing (in contrast to the residential part to the south, Unit II), an indicator of the outstanding social status of the house owner.

\section{THE RISE AND DEVELOPMENT OF THE BATHS IN THE HOUSE OF ORPHEUS}

The beginning of the insula dates back to the Hellenistic period during which this area was laid out in an orthogonal street grid and consisted of four units (Fig. 1). ${ }^{24}$ In later times, the original arrangement was drastically altered; but it seems that the layout of one of the central units (Unit II) was not much affected, permitting the reconstruction of the original plan with a central courtyard surrounded on three sides (W, N, E) by rooms of roughly equal size. The eastern ones could play the role of tabernae and workshops, possibly accessible directly from the street. The main entrance leading to the house was located in its south-eastern corner.

${ }^{24}$ They are of more or less equal width (within their perimeter walls) varying from $12.43 \mathrm{~m}$ to $14.40 \mathrm{~m}$ (the width of the southern one is uncertain, because it is not fully excavated). It should be stressed that the extent of the insula to the west is hypothetical, since all remains were ploughed away when the area was under cultivation, and further disturbed by British military activity during WWII. For the street grid, see the bibliography cited in footnote 18 . 
3. Bread oven (Hellenistic period?) and stratigraphy of room R 15 (Phot. D. Michaelides).

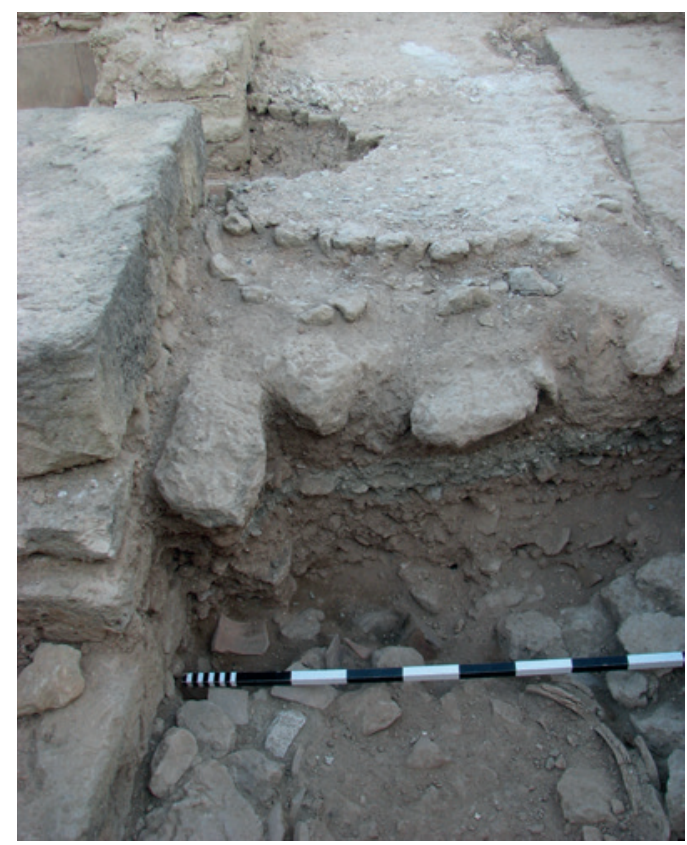

Understanding this original layout is crucial for the interpretation of the baths because their shape and functionality were undoubtedly influenced by pre-existing structures. A direct witness of such a structure was brought to light in the eastern part of room R 15. A bread oven found here belongs to an earlier phase of the insula, as evidenced by the preserved stratigraphy (Fig. 3, foreground). ${ }^{25}$ We must therefore make some assumptions even though at the same time and in the current state of research we need to be particularly cautious.

The analysis of the excavated area leads to the identification of at least two main phases of the bath suite. We can suppose that in the earliest phase the thermal installations were inserted in the north-easternmost limit of the excavated area, presumably occupying five rooms (R 15-19) along the eastern street, four of which belonged to Unit I and one to Unit II (the total area is $76 \mathrm{~m}^{2}$ ). Thus, these early baths formed an elongated, rectangular block including rooms located in what would originally have been the tabernae (R 15-18). Most of them correspond to the layout and size of the tabernae, identified also in the eastern-most part of Unit II (as R 19 and adjacent rooms) the only exception being the sequence of rooms R 16 and R 15 where the partition wall between them was shifted to the north. The interpretation of these rooms is based on both archaeological evidence and logical deduction. ${ }^{26}$

${ }^{25}$ For analogies for the bread oven, cf. Tell el-Timai in Egypt (Hudson 2016: 210, Figs 3, 10; Hellenistic), Tell Abu Sarbut in Jordan (square h, late Roman; see webpage: Tell Abu Sarbut) and Soussita in Israel (Segal et al. 2007: 20-22).

${ }^{26}$ A similar arrangement is characteristic of early thermal foundations; cf. Broise, Jolivet 1991 (especially p. 88 with plans). 
Already in the first phase, there must have been a furnace at the northern end of the baths, as evidenced by the surviving opening (which was later blocked), ${ }^{27}$ however, the room with the furnace itself has not been excavated. Room R 16 with a hypocaust, closest to room $\mathrm{R} 15$ identified as the praefurnium, was the caldarium. Room $\mathrm{R} 17$, also equipped with a hypocaust, being further away from the praefurnium, was cooler and must have served as the tepidarium. The lack of a room with a cold-water pool (frigidarium) is problematic, considering the fact that the alteration of hot and cold pools formed the core of the bathing routine. However, this is not all that surprising given that the frigidarium did not become a standard feature of baths before the middle of the first century $\mathrm{CE}^{28}$ The outermost room (R 19) from the adjacent unit, which was accessed directly from the vestibule (R 18), could have been adapted for the needs of the apodyterium. ${ }^{29}$ Thus, the bather would undress in the apodyterium, then return to the vestibule to progress through the tepidarium ( $\mathrm{R} 17$ ) to the hotter caldarium (R 16) (cf. Fig. 4a).

Already at this stage, the baths were accessible from both the street and the interior of the house. It is worth noting, however, that the passage from the vestibule (R 18) to the house was guarded by a solid door (as evidenced by the threshold between rooms $\mathrm{R} 18$ and R 14), which could indicate their semi-public (more than semi-private) character.

In the second phase, the baths were extended towards the west. They were remodelled and a set of rooms (R 11-14) was added parallel to the core of heated rooms. This modified the baths' size (up to $176 \mathrm{~m}^{2}$ ) and layout. As a consequence, a change of the circulation pattern occurred: from linear (where the bather progressed forward through a sequence of rooms, then retraced his/her steps), to the ring-type (where the bather proceeded through a sequence of rooms which brought him/her back to the starting point without the need to retrace one's steps).

The floor above the suspensura of the hot and warm rooms was completely destroyed (and removed) and no traces of fixed pools were found there. We cannot exclude the possibility that moveable basins and vessels were used in these rooms. However, it is very likely that there was at least one basin (a labrum?) in the caldarium, against the northern wall, near the praefurnium (Fig. 4b), where it could be filled with hot water from the alveus above the praefurnium.

This second-phase building was organised around a long rectangular room ( $\mathrm{R} 14$ ) oriented north-south, which was presumably both an apodyterium ${ }^{30}$ and a frigidarium

${ }^{27}$ This could be related with the putting up of an additional wall, probably to reinforce the original one, the structure of which was damaged, perhaps as a result of an earthquake.

${ }^{28}$ Maréchal 2020: 153-154, especially n. 22. Perhaps we should also consider the possibility of a portable bathtub being used.

${ }^{29}$ In the southern wall of room R 18, a block served probably as a kind of step leading to room R 19 which has a slightly higher floor level (the entire excavated area clearly rises towards the south). On the opposite side, in the northern wall of the room $\mathrm{R} 18$, there was a symmetrically located doorway leading to room $\mathrm{R} 17$; this opening was later blocked with masonry; preserved traces of the painted decoration clearly indicate the second phase activity.

${ }^{30}$ The apodyterium accessible from the vestibule could be left for the use of people from outside the household, entering the baths from the street. 


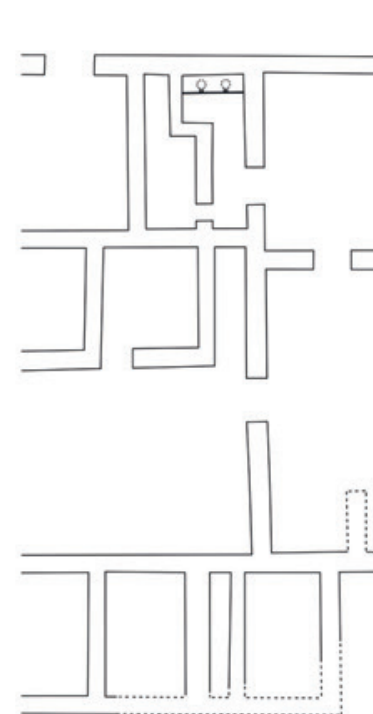

a

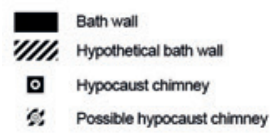

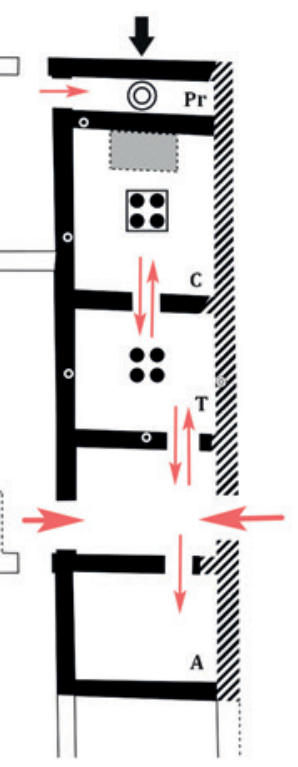

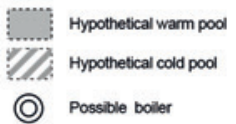

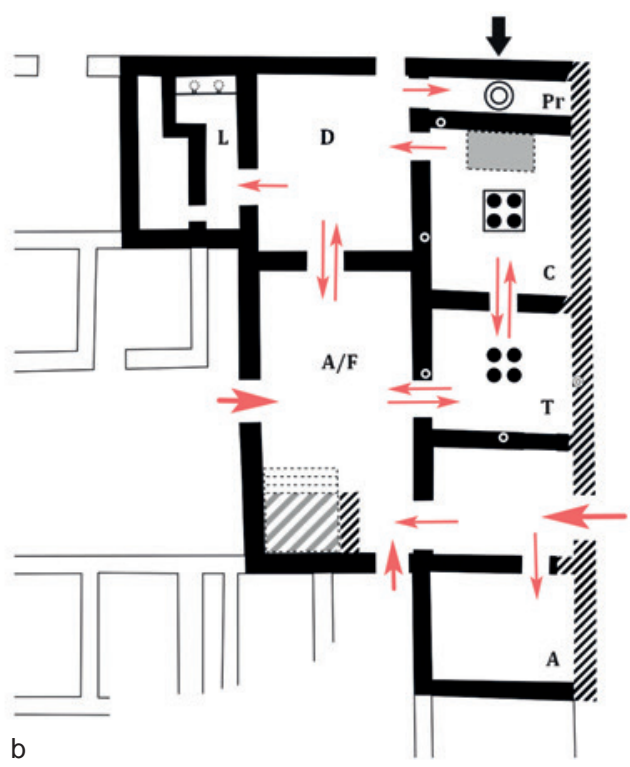

b

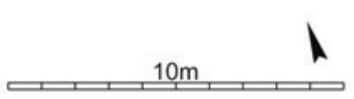

Hypocaust without wall heating

Fumace

4. Bath suite, reconstruction of the circulation pattern: a. first phase; b. second phase; A - apodyterium, $\mathrm{T}$ - tepidarium, C-caldarium, F - frigidarium, Pr - praefurnium, D - destrictarium (Drawing: J. Kaniszewski).

with a built pool in the SW corner. ${ }^{31}$ Such multifunctionality is not uncommon in baths of a similar size. The apodyterium/frigidarium, the largest room, was a walk-through space with at least one door in each wall, constituting a central communication node. The door set in the eastern wall allowed connection with the outside of the house via a vestibule. Communication inside the house was assured by two passages: a southern one from the residential part and a western one from the reception area. There was another passageway to the north that led to room R 13 through which one could access the latrinae (R 12). ${ }^{32}$

Room R 13 was paved with hydraulic mortar (opus signinum) and was also (beside room R 14) a kind of communication node with doors in each wall. The hydraulic mortar is made with tiny pebbles and some ground pottery, and the quarter round moulding is reinforced

${ }^{31}$ Evidence for such a pool is probably provided by remnants of a N-S oriented wall (c. $0.95 \mathrm{~m}$ long) visible at a distance of $1.3 \mathrm{~m}$ from the western wall. Other remains are hidden under the mortar from the post-thermal period. However, the preserved traces are few, and such a hypothesis remains conjectural. The analogy to this type of solution is to be found in the Stabian Baths of Pompeii; cf. Trümper 2020: Fig. 2.

32 The toilet originally had two wooden or stone seats resting on a ledge in the wall (for a parallel of a double toilet, cf. the example in the Maison de la Chasse in Bulla Regia: Carucci 2007: 121). The shape of this room as well as that of a storage(?) room behind it (R 11), resulted from the erection of a single flight of stairs leading to a now-lost upper level. 

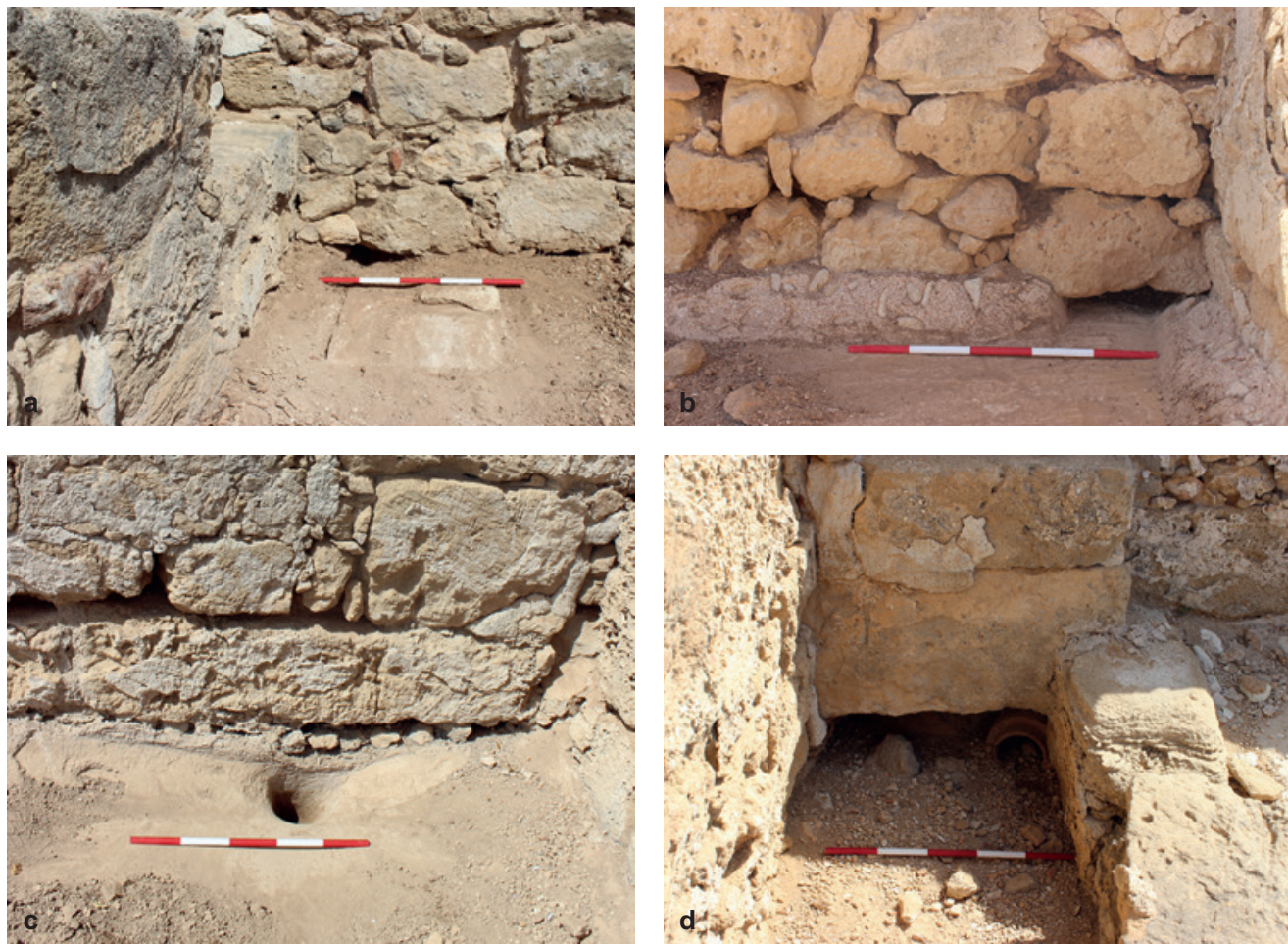

5. Passages in the wall between rooms R 14 and R 13 (a. south side, b. north side) and between rooms R 13 and R12 (c. east side, d. west side) (Phot. M. Rekowska).

with largish pebbles that can be seen on Fig. $\mathbf{5 b}$. The above-mentioned narrow northern entrance also served those operating the praefurnium. The location of the room and its hydraulic floor would indicate that the room was used as a destrictarium, the place for rubbing down the body after exercise.

Accessibility from the inside and the outside of the house, with a street entrance which allowed one to enter the baths without disturbing the private parts of the house, as well as the two possible apodyteria, reinforce the hypothesis about the double use of the baths. ${ }^{33}$

The closest known parallel for such a bath suite is provided by the Villa of Theseus, which has a similar pattern of circulation and arrangement of rooms, all of which suggest that there were no major differences between the bathing routine in the House of Orpheus and that in the Villa of Theseus. ${ }^{34}$ The most striking difference was their size in square meters, though this is understandable, considering the relative size of the two buildings.

${ }^{33}$ Such duality (private/public) is not uncommon in Cyprus (i.a. in Kourion: House of Gladiators, Building of Eustolios) and several sites in Asia Minor. It has also been suggested for the bath in the Villa Romana del Casale at Piazza Armerina, and for the bath in the Villa at Makryialos in Crete, although in a rural context (see: Kelly 2004: vol. I, 141-142).

${ }^{34}$ Daszewski 1972; 1976. 
The whole bath suite was presumably covered with a flat roof. However, the heated rooms - because of the humidity there - must have been vaulted. The rooms are narrow enough to be easily covered by a vault of a $c .4 .2 \mathrm{~m}$ span. ${ }^{35}$

The baths' orientation and location in the north-eastern corner of the house is contrary to Vitruvius' instructions (De arch. V.10.1), as it situates the hot rooms in the south-west. ${ }^{36}$ This, however, is a phenomenon exclusive to Paphos and the region (Villa of Theseus, Ayios Georgios of Peyeia), the baths in the rest of the island being canonical. Other features of the House of Orpheus baths, such as the use of tiles for the floor and the walls, and the dimensions, are as Vitruvius recommends. In any case, the hot climate of Cyprus and the generally warm winters of Paphos did not make Vitruvius' recommendation imperative. Furthermore, windows set into the long, load-bearing wall along the eastern street would allow the pleasant morning sun to enter the baths.

\section{TECHNOLOGY}

\section{WATER MANAGEMENT}

Questions regarding the water supply of the baths, and the house as a whole, cannot as yet be answered. No installations survive in situ but, given the plethora of clay pipes throughout the site, it can be assumed that water was supplied and distributed via pipeline(s).$^{37}$ It is not clear, however, where the water came from..$^{38}$ It could have come from an underground cistern (well?), the mouth of which is located in the SW corner of the alleged courtyard (R 6), or some reservoir outside the house.

There is, furthermore, one bit of evidence, in relation to room R 13 . An opening at the root of the western end of the wall separating room R 13 from room R 14 (Fig. 5a) leads to an outlet on the floor of room R 13 (Fig. 5b). Unfortunately, the floor of room R 14 is not well preserved, and although patches of mortar survive, this does not seem to have had hydraulic properties. By contrast and as mentioned already, room R 13 was not only paved with very good quality hydraulic mortar, but was also provided with a substantial quarter round moulding, between floor and walls, reinforced with large pebbles. This indicates

35 The room height is calculated in relation to the distance between the $\mathrm{E}$ and $\mathrm{W}$ walls of the heated rooms, according to Vitruvius' instructions (De arch. V.10.5); and the barrel-vault, made of wooden planks, is reconstructed in analogy to similar structures in Pompeii (see: Anderson, Robinson 2018: 106) and elsewhere (see: Dobosi, Borhy 2015: 192-194; Monturet, Rivière 1986: Pl. 25).

${ }^{36}$ Always bearing in mind that Vitruvius' relevance to the East can be questioned.

${ }^{37}$ For a discussion of the water supply of this general area and the possibility of an aqueduct serving Paphos in the first century CE, see: Romaniuk 2021: 387-389, 392, in the present volume. We must note, however, that according to Marcin Romaniuk's observations 'the rainwater harvesting (possibly along with the drawing of water from the wells and local streams) was a primary source of water'.

${ }^{38}$ In the House of Orpheus the baths were probably supplied entirely with water stored in the cisterns, as was the case in numerous Roman baths in Cyprus. Christodoulou mentioned 'two large cisterns', only one of them indicated on the plan (Christodoulou 2014a: Fig. 14). This identification is, however, erroneous; cf. Rekowska et al. 2019: Fig. 14. 
that activity in room R 13 involved a lot of water. Nonetheless, the walls are not lined with hydraulic mortar, which precludes the use of the space as a pool.

Water was fed through the above-mentioned hole connecting rooms R 14 and R 13 but where it came from cannot be established. It may have been brought to the corner of room R 14 by clay pipes or it may have come from a now-lost reservoir/pool in this room, where rainwater harvested from the roof was collected through downpipes (of different types seen elsewhere on the site). ${ }^{39}$ Furthermore, one must not exclude the possibility of the water being supplied from a roof tank. ${ }^{40}$ Access to the roof, if deemed necessary, was provided by a narrow staircase in adjacent room $\mathrm{R} 9$.

The question of how waste water was disposed of poses no problem. Usually, dirty water was drained by a system of channels running underneath the floor. ${ }^{41}$ In such a case, the channels had to be designed and laid out at the initial stages of the construction. As the baths in the House of Orpheus were incorporated into the pre-existing buildings, another solution was found, which avoided unnecessary effort and the destruction of the earlier floors. The evidence comes from room R 13 but the system was probably applied to other rooms too. Instead of building a channel, the hydraulic floor was laid at a gentle slope and the waste water flowed towards an outlet at the root of the northern part of the wall separating rooms R 13 and R 12 (Fig. 5c).There are remnants of a hydraulic mortar floor in room R 12 and perhaps elsewhere, but only the flooring in room R 13 is fully preserved, allowing observation of this intentional sloping of the floor (Fig. 6). The dirty water was thus directed towards the low-lying drainage hole, flushed away any waste from the latrines (R 12) (Fig. 5d), and all ended in the main sewer under Street B, with which the system was connected. An additional benefit of this process was that the oil and dirt that had accumulated on the bathroom floors could also be disposed of at the same time. ${ }^{42}$

We cannot, however, suggest anything regarding the drainage from the hypothetical hot-water pool in the caldariun since, as mentioned already, all traces of floor and pool were completely destroyed.

\section{HEATING SYSTEM AND HEAT DISTRIBUTION}

A heating apparatus consisting of underfloor and wall heating allows the control of the variation in temperature between the hot and warm rooms (Fig. 7).

From the furnace (praefurnium, R 15), situated immediately to the north of the caldarium, the hot air was directed into the interconnecting hypocaust system under

39 Romaniuk 2021: 383-385.

40 Yegül 1992: 390.

${ }^{41}$ Romaniuk 2021: 383-385.

${ }^{42}$ It is interesting to find the same system used in the piscina of the women's frigidarium of the Stabian Baths in Pompeii (cf. Maréchal 2017: 180, Fig. 2). As Sadi Maréchal observed 'pools that were added in a later phase, and hence constructed on top of an existing floor, often had such a drain, as this saved the effort of breaking open floors to lay out sewers' (Maréchal 2017: 185, n. 7). This fits well with our proposition that the frigidarium/apodyterium (R 14) was constructed during the second phase of the House of Orpheus bath suite. 


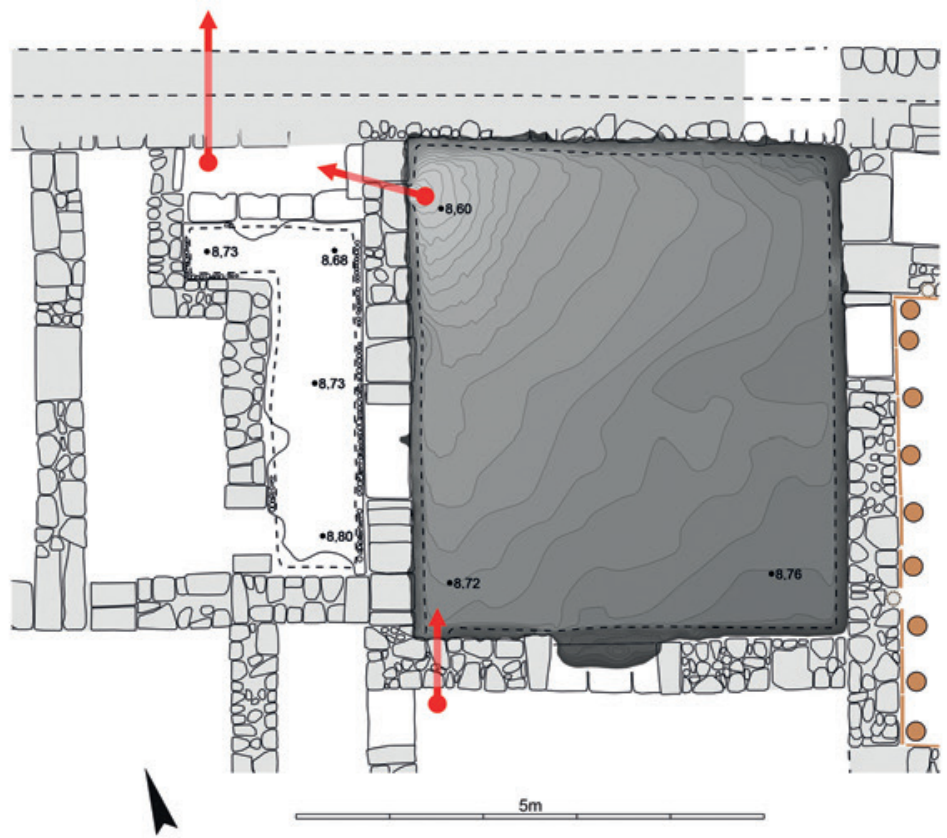

6. Water disposal system in room R 13 (Drawing: J. Kaniszewski).
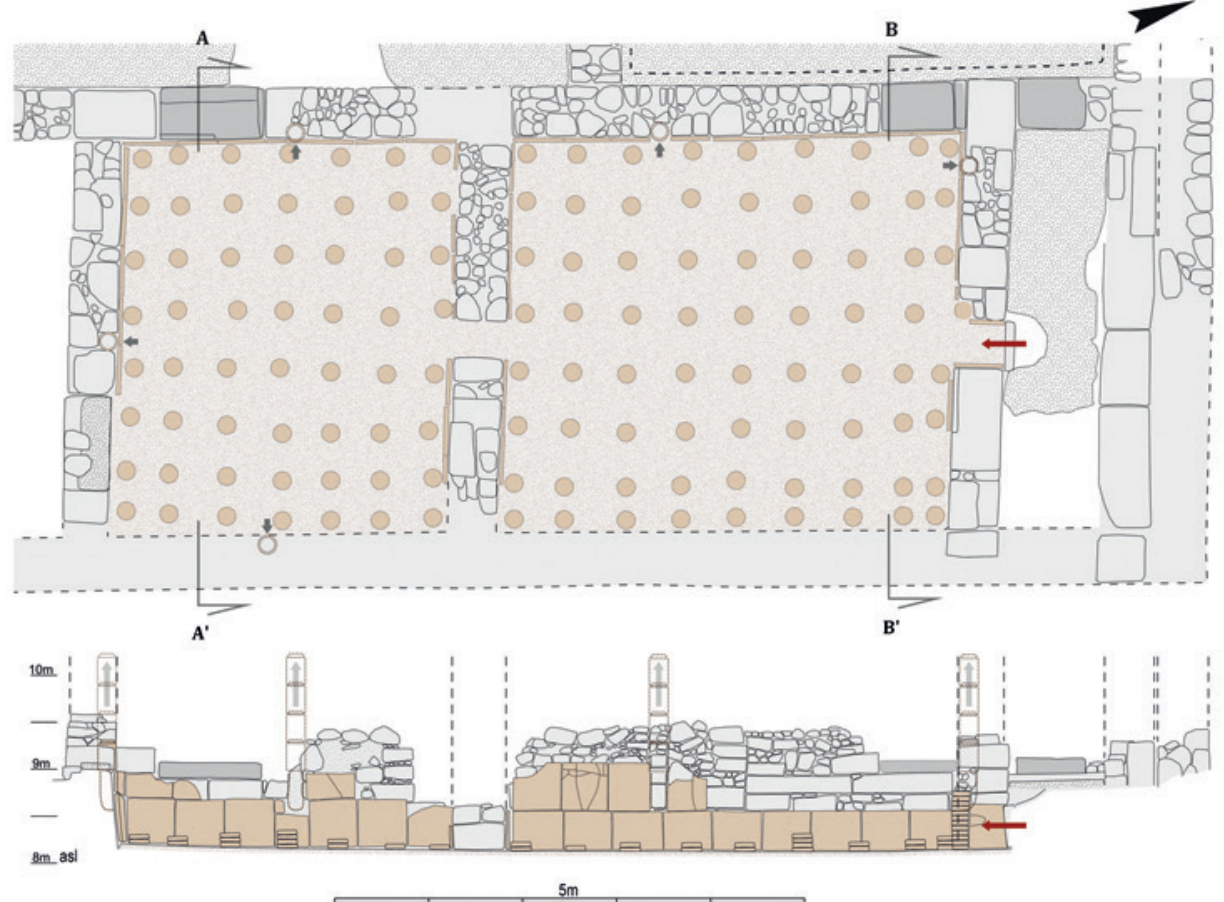

7. State of conservation of the heated rooms of the baths (R 16 and R 17): layout and elevation (Drawing: J. Kaniszewski). 


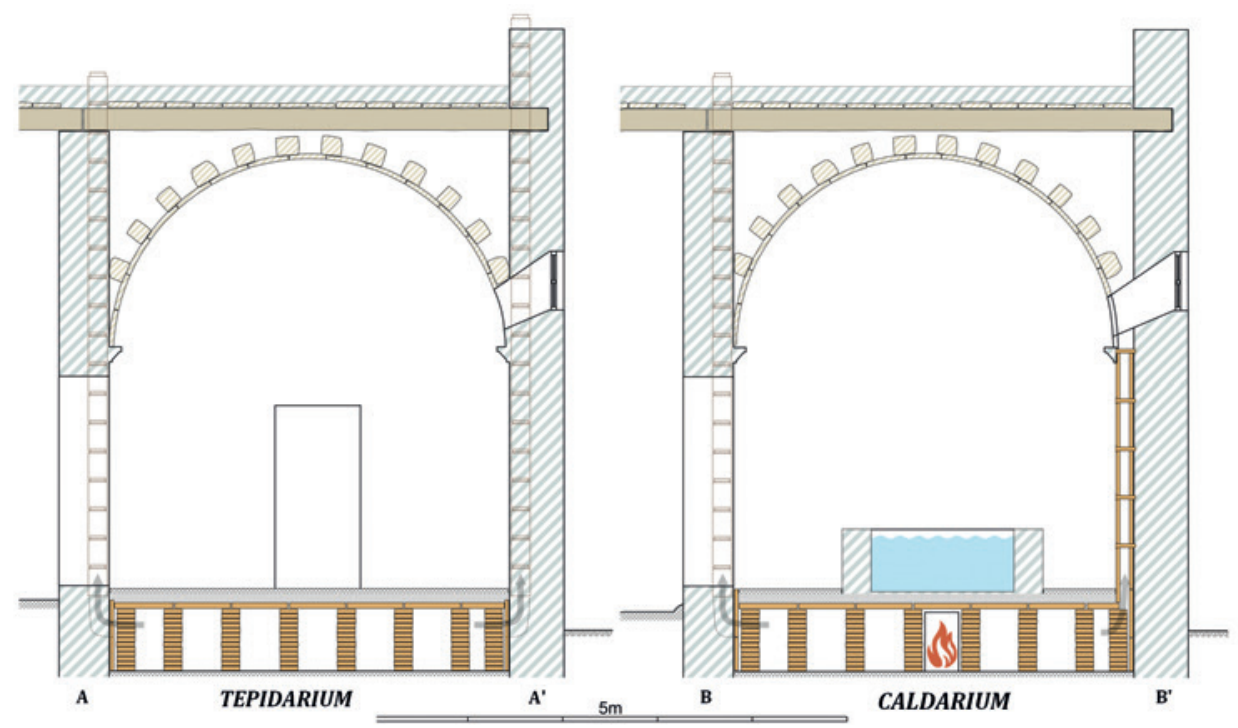

8. Hypothetical reconstruction of the heated rooms: AA'. cross section through tepidarium (view to the north; cf. Fig. 7); BB'. cross section through caldarium (view to the north; cf. Fig. 7) (Drawing: J. Kaniszewski).

the caldarium (R 16) and the tepidarium (R 17; Fig. 8). It should be noted that, as mentioned before, the passage through which the hot gasses passed from the praefurnium to the hypocaust, was blocked at a later stage with a square tile $(42 \mathrm{x} 42 \mathrm{~cm}){ }^{43}$

Surviving evidence at the north end of the caldarium, shows that the suspensura must have been at a height of about $1.3 \mathrm{~m}$ from the floor of the furnace. It was supported by pilae made of stacks of circular tiles (diameter c. $20 \mathrm{~cm}$ ). As per Vitruvius' instructions (De arch. V.10.2) these pillars were about two feet high $(60 \mathrm{~cm})$, as can be deduced from the traces of the level of the now-lost floor along the walls. The floor of the hypocaust in the caldarium and the tepidarium is covered with coarse hydraulic mortar. It is worth mentioning that, in some places in the caldarium, the mortar bears imprints of the circular bricks, which do not correspond to the regularly arranged pilae. These are probably the result of the temporary placing of the bricks on the ground while the craftsman built the pilae to the desired height, although if that were the case, one would also expect imprints of the craftsmen's feet. We cannot therefore rule out that these are remnants of repair of the hypocaustum. One also notes, especially along the northern and eastern walls of the caldarium, that there are extra pilae, indicating that at these points the pilae supported halved tiles, or that these were added at a later stage in order to support a weakened section of the floor, or even that a restructuring of the suspensura had taken place.

On the south wall of the tepidarium there are, still in situ, two connected clay pipes of circular cross-section, which functioned as air-conduits (cuniculi), the lower part of which

\footnotetext{
43 See above and footnote 27.
} 


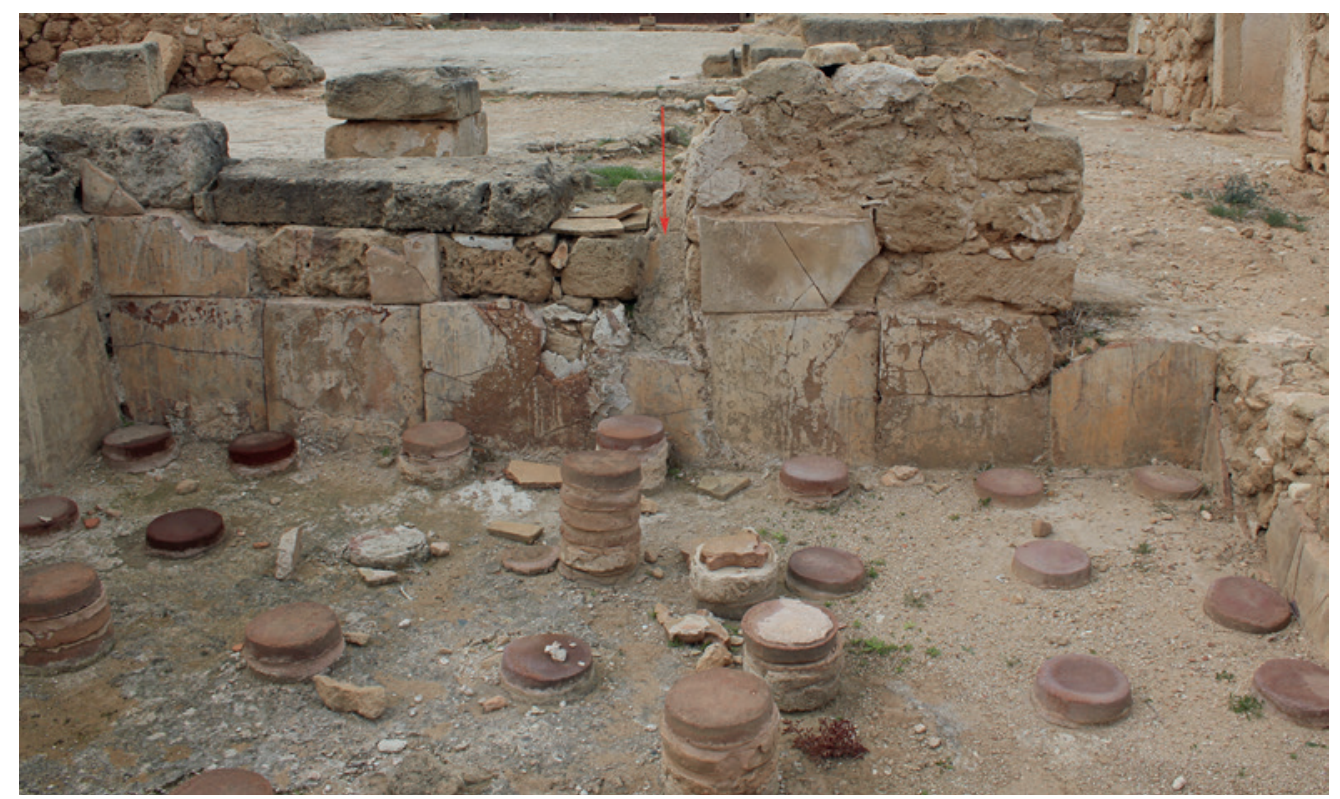

9. West wall in room R 17; the circular air duct can be seen in the middle (Phot. S. Christodoulou).

communicated with the hypocaust. A fair number of such pipes was also found in the caldarium and tepidarium. Square air ducts appear to have been built into the west wall of both heated rooms (Fig. 9). Unfortunately, the east wall of the rooms is not preserved, but it is speculated that it would have had corresponding air ducts. In the construction of the walls, provision was made to create a gap, into which the specially shaped clay air-ducts (c. $10 \times 15 \mathrm{~cm})$ would be placed. They were fixed in place with mortar, still visible today.

The study of the archaeological material shows that the walls were heated with the spacer-pin method, allowing the hot gasses to pass through a 'gap' in the wall and thus heat the tepidarium and the caldarium, also protecting them from humidity. The lower part of the walls of the caldarium and the tepidarium - that corresponding to the section under the suspensura - was covered with large (52 x 52cm), plain square terracotta tiles, $3 \mathrm{~cm}$ thick. A large number of such tiles was found in the debris between the pilae, but, as we will see, their use was different. Together with the tiles, twenty-three complete clay spacer pins and at least another eighty-five fragments of pins were found (Fig. 10a-c). ${ }^{44}$ The stems of the clay spacer pins have a length of about $15-22 \mathrm{~cm}$ and are circular in section. One end is rounded, while the other end is rectangular (varying from $c$. 3-6 3 6-8cm). The rounded ends of the pegs were fixed into the tile-covered wall, while other terracotta tiles would be fixed on a constriction, about $3-4 \mathrm{~cm}$ from the rectangular head. This created a gap through which the hot air circulated and heated the walls of the rooms. Some pegs have another shallow constriction in the middle of the stem (Fig. 10d), which was cut by hand when the

${ }^{44}$ Christodoulou 2014b: 397-402. 
a
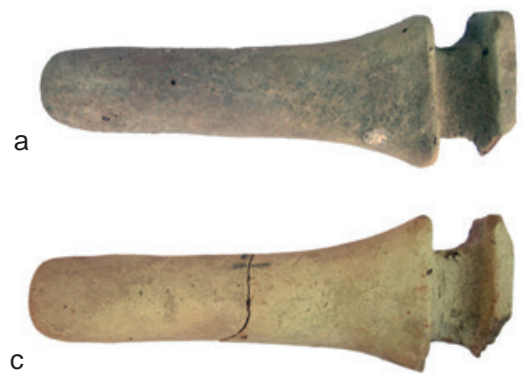

b

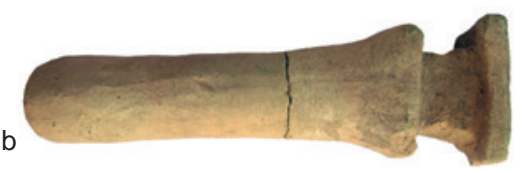

d

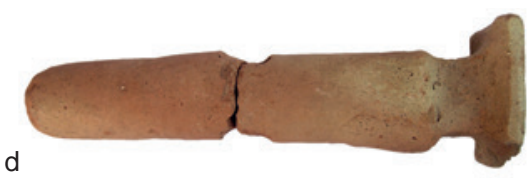

0 $10 \mathrm{~cm}$

10a-d. Spacer pins found in the baths (Phot. S. Christodoulou).

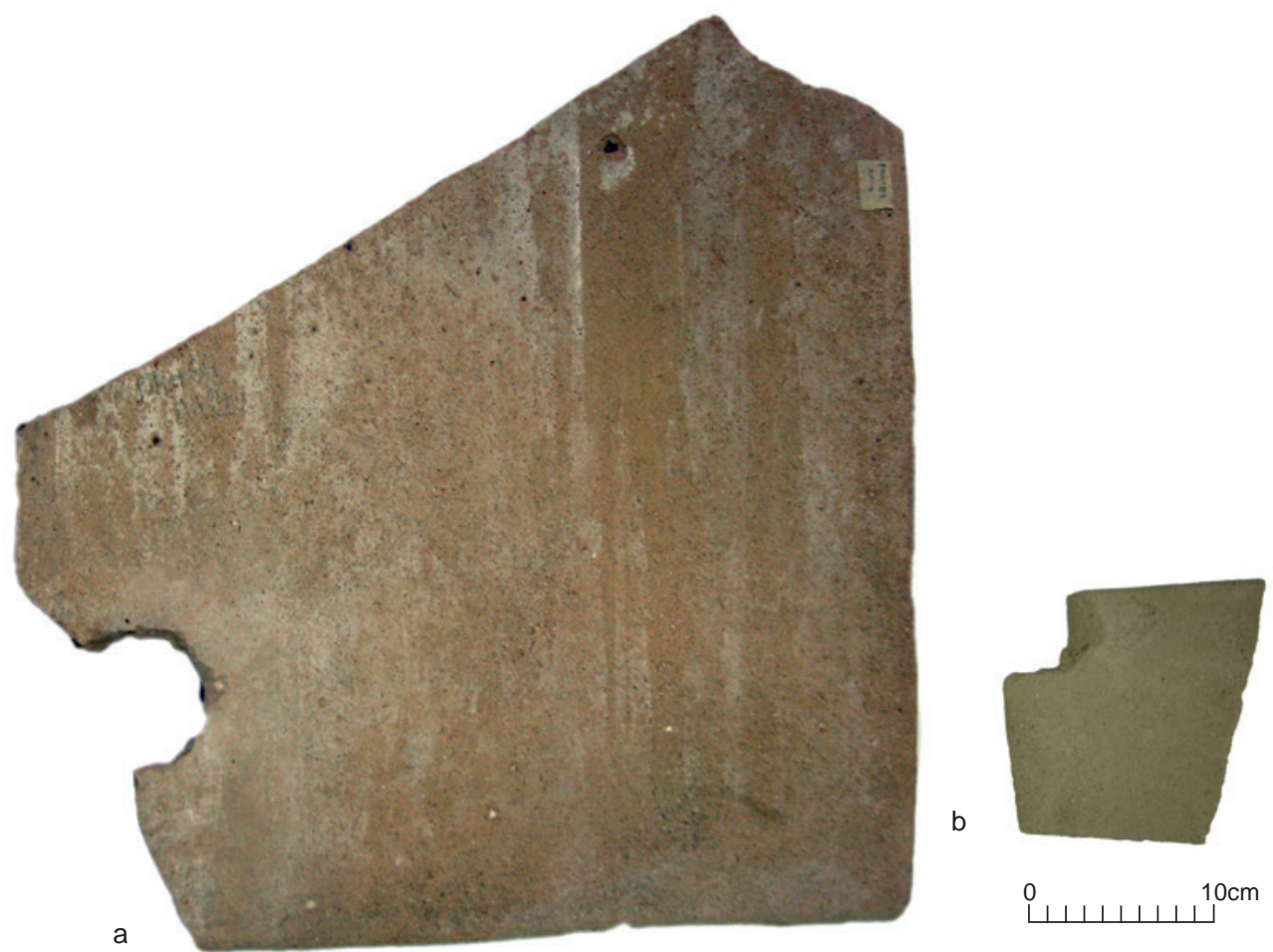

11a-b. Terracotta tiles from the baths (Phot. S. Christodoulou).

clay was still soft, and which helped to better fix the ceramic tiles on the wall. As in the House of the Gladiators at Kourion, there are tiles with specially cut circular holes, through which the peg was fixed on the wall (Fig. 11a). ${ }^{45}$ A second group of ceramic tiles had their

\footnotetext{
${ }^{45}$ Christodoulou 2014b: 390-392.
} 
corners cut away in order to fit them better on the constriction near the square end of the spacer pins (Fig. 11b).The shafts of the pins are always broken at more or less the same point, indicating which section of the pin was fixed into the wall. This measured $c .8-10 \mathrm{~cm}$, thus giving an approximate width of $7-12 \mathrm{~cm}$ for the gap created between the support wall and parallel tiles through which the hot air circulated. This simple and economic system of heating spread widely in the Eastern Mediterranean and was applied even in big, public complexes, attested in Asia Minor, Crete as well as elsewhere in Cyprus. ${ }^{46}$

\section{CONCLUSIONS}

In Roman cities, where public baths were generally easily accessible, private baths were a sign of luxury. Their presence testifies to the high living standard of the house owner, while, at the same time, it was a means of impressing clients and guests through a display of power and wealth. The supposed commissioner of the mosaic of Orpheus was probably an important, influential and powerful member of the Nea Paphos community. Therefore, his house was a way of his self-presentation, and baths were an indicator of his high status, both socially and financially. In order to properly appreciate this status, the bath suite would have to be analysed on different levels bringing into relief the facilities offered in the baths and the quality of the decoration. ${ }^{47}$

The reconstruction of the decoration remains problematic. Down through the ages this area was used as a 'quarry' for building material and little of the decoration has survived. Just single tesserae and a few fragments of white, red, green and blue painted plaster found in the fill between the pilae are probably evidence of decorated mosaic floors and colourful wall paintings, although given the complete removal of the suspensura and the general disturbance of the area, such finds may have come from elsewhere.

In the absence of decoration, we can evaluate the high quality of the facilities offered - facilities that did not differ from those in private baths all over the Empire. This is evidenced by the elaborate sequence of specialised rooms, the water supply infrastructure and the hypocaust heating system. In order to maintain the expected standards, the builders coped perfectly with the challenge of integrating the baths into the pre-existing buildings of a Hellenistic period house. There are many indications that rooms in Unit I alongside the street were used then for this purpose. However, in order to obtain the required layout, an additional room (in Unit II) was added to the whole complex. While the baths from the first phase were quite a modest five-room block, the extended bath suite from the second phase, evidently inspired by Western models, even if the use of spacer pins remains a specifically Eastern feature, was quintessentially Roman. ${ }^{48}$ The extension of the baths required

${ }^{46}$ Faka et al. 2017: esp. Fig. 8; Christodoulou 2014a; 2014b; Kelly 2013: 136-137; Farrington 1995; Farrington, Coulton 1990; Uytterhoeven 2011: 321.

47 De Haan 2010: 71.

48 The lack of fixed basins makes the interpretation troublesome, but logical deduction based on analogous examples from other bath suites in a private context allows us to formulate credible hypotheses. 
the adaptation of the living space in Unit I, which radically changed the character of this part of the house. Private life was moved to Unit II, while Unit I became a public space, accessible to those visiting the residence. ${ }^{49}$

We do not have any certain information on the identity of the house owner. However, given the Latin name recorded in the mosaic inscription we can propose that [-]us Pinnios Restitutos was the owner - perhaps a rich Roman official, administrator, rich negotiator or maybe a deserving veteran..$^{50}$

We can imagine the house owner carefully monitoring the access to various parts of the representation wing, and we can hypothesise that the official guests were invited to a banquet in a triclinium with a mosaic decorated with representations of an Amazon and of Hercules, while the amici had the pleasure of more intimate conversations in a mosaic room with Orpheus. Selected visitors needed a special invitation to go to the baths where social and business talks in a casual atmosphere could be carried out. And, as history shows, powerful men in society have always dictated a society's character.

On the other hand, publicly accessible bathing facilities or the act of offering baths to the urban community could also be a display of the owner's euergetism and a message of social hierarchy sent to a much wider public. The idea of using baths to secure the higher ranking of the benefactor in the eyes of the public was also essentially Roman. In such a context, a bath suite in a private residence, influenced by models occurring in Italy, might be interpreted as an indicator of the owner's Romanitas.

'The large public baths that one assumes existed in Nea Paphos (...) have yet to be located'. ${ }^{51}$ This is a safe assumption given that Nea Paphos was the capital of Roman Cyprus and no doubt had large public baths like those found at Salamis and Kourion. All the same, it seems reasonable to ask whether and to what extent thermal installations in private residences, albeit open to the public, complemented such large establishments. In any case, the bathing block in the House of Orpheus presented here is the earliest known bath system in Nea Paphos and was the ostentatious manifestation of Roman culture. ${ }^{52}$

\section{Acknowledgements}

The article has been written within the framework of the project 'Residence as a Self-presentation of Urban Elites. Architecture and Decoration of the House of Orpheus in Nea Paphos, the Ancient Capital of Cyprus' financed by the National Science Centre (NCN), Poland UMO-2017/27/B/HS3/01131.We would like to thank both reviewers for their invaluable comments and suggestions, thanks to which the text gained clarity and substantive value.

\footnotetext{
${ }^{49}$ See in this context Andrew Wallace-Hadrill's discussion of public and private space in Pompeian houses: Wallace-Hadrill 1994; Laurence, Wallace-Hadrill 1997.

${ }^{50}$ For the 'Western' character of private baths in houses in Greece and Asia Minor, see: Bonini 2006; Uytterhoeven 2020.

${ }^{51}$ Christodoulou 2014a: 96.

52 Ellis 2000: 160.
} 


\section{References}

Anderson, M., Robinson, D. 2018: House of the Surgeon, Pompeii. Excavations in the Casa del Chirurgo (VI I, 9-10.23), Oxford

Bonini, P. 2006: La casa nella Grecia romana. Forme e funzioni dello spazio privato fra I e VI secolo, Antenor Quaderni 6, Roma

Broise, H., Jolivet, V. 1991: Le bain en Étrurie à l'époque hellénistique, [in:] Thébert, Y. (Ed.), Les thermes romains. Actes de la table ronde de Rome (11-12 novembre 1988), CEFR 142, Rome, 79-95

Carucci, M. 2007: The Romano-African Domus. Studies in space, decoration, and function, BAR-IS 1731, Oxford

Cayla, J.-B. 2018: Les inscriptions de Paphos : la cité chypriote sous la domination lagide et à l'époque impériale, Lyon

Christodoulou, S. 2014a: Ancient Baths in Cyprus, [in:] Boussac, M.-F., Denoix, S., Fournet, T., Redon, B. (Eds), 25 siècles de bain collectif en Orient. Proche-Orient, Égypte et péninsule Arabique. Actes du $3^{\mathrm{e}}$ colloque international Balnéorient, organisé par l’Institut Français du Proche-Orient et la Direction Générale des Antiquités et des Musées de Syrie (Damas-Syrie/2-6 nov. 2009), Le Caire, 83-106

Christodoulou, S. 2014b: Ta loutra kata tēn Ellēnistikē kai Rōmaïkē periodo stēn Kypro, unpublished PhD thesis, Department of History and Archaeology, University of Cyprus, Nicosia

Christou, D. 2007: Kourion. Its Monuments and Local Museum, Nicosia

Daszewski, W.A. 1970: Polish excavations at Kato (Nea) Paphos. Second preliminary report: seasons 1968 and 1969, RDAC 1970, 112-141

Daszewski, W.A. 1972: Polish Excavations at Kato (Nea) Paphos in 1970 and 1971, RDAC 1972, 204-236

Daszewski, W.A. 1976: Les fouilles polonaises à Nea Paphos 1972-1975. Rapport préliminaire, RDAC 1976, 185-225

Dobosi, L., Borhy, L. 2015: Roman Building Techniques Observed in the Municipium of Brigetio, Acta Archaeologica Academiae Scientarum Hungaricae 66, 183-201

Donderer, M. 1989: Die Mosaizisten der Antike und ihre wirtschaftliche und soziale Stellung. Eine Quellenstudie, Erlanger Forschungen. Reihe A, Geisteswissenschaften 48, Erlangen

Ellis, S.P. 2000: Roman Housing, London

Fagan, G.G. 1999: Bathing in public in the Roman world, Ann Arbor

Fagan, G.G. 2001: The Genesis of the Roman Public Bath: Recent Approaches and Future Directions, AJA 105/3, 403-426

Faka, M., Christodoulou, S., Abate, D., Ioannou, C., Hermon, S. 2017: A 3D based approach to the architectural study of the Roman bath at the Sanctuary of Apollo Hylates (Kourion, Cyprus), ISPRS Annals of the Photogrammetry, Remote Sensing and Spatial Information Sciences IV-2/W2, 91-98, https://doi.org/10.5194/isprs-annals-IV-2-W2-91-2017 (accessed February 28, 2021) 
Fales, De Coursey Jr. 1950: Kourion - The amusement area, PUMB 14/4, 27-37 Farrington, A. 1995: The Roman Baths of Lycia. An Architectural Study, British School of Archaeology at Ankara Monographs 20, London

Farrington, A., Coulton, J.J. 1990: Terracotta Spacer Pins in Lycian Bath Buildings, AnatStud 40, 55-67

Haan, N. de 2010: Private luxury and public prestige. Roman private baths, [in:] Hekster, O., Mols, S.T.A.M. (Eds), Cultural Messages in the Graeco-Roman World. Acta of the BABESCH $80^{\text {th }}$ Anniversary Workshop, Radboud University Nijmegen, September $8^{\text {th }}$ 2006, BAB Suppl. 15, 67-78

Hudson, N. 2016: A Hellenistic Household Ceramic Assemblage from Tell el-Timai (Thmuis), Egypt: A Contextual View, BASOR 376, 199-244

Karageorghis, V. 1972: Chronique des fouilles et des découvertes archéologiques a Chypre en 1971, BCH 96/2, 1005-1088

Kelly, A. 2004: The Roman aqueducts and bathhouses of Crete, unpublished PhD thesis, Trinity College, Dublin

Kelly, A. 2013: Roman bathhouses on Crete as indicators of cultural transition: the dynamics of Roman influence, [in:] Gardner, A., Herring, E., Lomas, K. (Eds), Creating Ethnicities \& Identities in the Roman World, BICS-Suppl. 120, 131-167

Kondoleon, Ch. 1982: Kourion City. The mosaics - Area I \& II, [in:] Wylde Swiny, H. (Ed.), An archaeological guide to the ancient Kourion area and the Akrotiri Peninsula, Nicosia, 98-105

Krencker, D., Krüger, E. 1929: Die Trierer Kaiserthermen, Augsburg

Laurence, R., Wallace-Hadrill, A. (Eds) 1997: Domestic space in the Roman world: Pompeii and beyond, JRA Suppl. 22, Portsmouth

Loulloupis, M. 1971: Anaskafai eis Kourion, 1967-1970. Ē oikia tōn monomachōn, $R D A C$ 1971, 86-116

Maréchal, S. 2017: A note on the drainage of pools in Roman baths, $B A B$ 92, 179-186

Maréchal, S. 2020: Not your classic bath: adopting and adapting Roman bathing habits in NW Gaul, JRA 33, 147-168

Meyza, H., Słowińska, M., Tybulewicz, R., Woźniak, M. 2014: Nea Paphos: Seasons 2010 and 2011, PAM XXIII/1, 391-411

Michaelides, D. 1986: A New Orpheus Mosaic in Cyprus, [in:] Karageorghis, V. (Ed.), Acts of the International Archaeological Symposium 'Cyprus between the Orient and The Occident', Nicosia, 8-14 September 1985, Nicosia, 473-489

Michaelides, D. 1987: A catalogue of the Hellenistic, Roman and Early Christian mosaics of Cyprus with representations of human figures, RDAC 1987, 239-252

Michaelides, D. 1992: The Conservation of the Orpheus Mosaic in Paphos, Cyprus, ICCM (International Committee for the Conservation of Mosaics) Newsletter 9, 14-17

Michaelides, D., Daszewski, W.A. 1988: Guide to the Paphos Mosaics, Nicosia

Miszk, Ł., Ostrowski, W., Papuci-Władyka, E. 2020: Appendix: Some Remarks on Urban Layout of Nea Paphos, [in:] Papuci-Władyka, E. (Ed.), Interdisciplinary Research 
of the Jagiellonian University in Nea Paphos UNESCO World Heritage Site (2011-2015) - First Results, Paphos Agora Project 1, Cracow, 527-530 Mitford, T.B. 1971: The inscriptions of Kourion, MAPS 83, Philadelphia Młynarczyk, J. 1990: Nea Paphos in the Hellenistic Period, Nea Paphos III, Varsovie Monturet, R., Rivière, H. 1986: Les thermes sud de la villa gallo-romaine de Seviac, Aquitania Suppl. 2, Paris-Bordeaux

Nicolaou, K. 1970a: Archaeological News from Cyprus, 1968, AJA 74/1, 71-78

Nicolaou, K. 1970b: Archaeological News from Cyprus, 1969, AJA 74/4, 391-400

Nicolaou, K. 1972: Archaeological News from Cyprus, 1970, AJA 76/3, 311-320

Nicolaou, K. 1973a: Archaeological News from Cyprus, 1971, AJA 77/1, 51-60

Nicolaou, K. 1973b: Archaeological News from Cyprus, 1972, AJA 77/4, 425-433

Nicolaou, K. 1975-1976: Archaeology in Cyprus, 1969-76, ArchRep 22, 34-69

Nicolaou, K. 1983: Three new mosaics at Paphos, Cyprus, [in:] Farioli Campanati, R. (Ed.), III Colloquio internazionale sul mosaico antico, Ravenna, 219-225

Nielsen, I. 1990: Thermae et Balnea. The Architecture and Cultural History of Roman Public Baths, vols 1-2, Aarhus

Papuci-Władyka, E. 2020: Paphos Agora Project (PAP): its Aims, Stages of Development, Methodology and Chronology, [in:] Papuci-Władyka, E. (Ed.), Interdisciplinary Research of the Jagiellonian University in Nea Paphos UNESCO World Heritage Site (2011-2015) - First Results, Paphos Agora Project 1, Cracow, 73-89

Rebuffat, R. 1969: Maisons à péristyle d'Afrique du Nord : répertoire de plans publiés, MEFRA 81/2, 659-724

Rekowska, M., Michaelides, D., Pensabene, P., Gasparini, E. 2019: A New Project in Progress: Residence as Self-presentation of Urban Elites. Architecture and Decoration of the House of Orpheus in Nea Paphos, the Ancient Capital of Cyprus. Potentials and Prospects, Światowit LVIII, 197-218

Rekowska, M., Michaelides, D., Pensabene, P., Gasparini, E. 2021: The House of Orpheus at Nea Paphos, Cyprus: the evolution of domestic space in a diachronic perspective, [in:] Baldini, I., Sfameni, C. (Eds), Abitare nel Mediterraneo tardoantico. Atti del III Convegno Internazionale del Centro Interuniversitario di Studi sull'Edilizia abitativa tardoantica nel Mediterraneo (CISEM) (Bologna 28-31 ottobre 2019), Insulae Diomedeae 42, Bari, 37-52

Romaniuk, M.M. 2021: Terracotta Pipelines at Maloutena. Remarks on the Water System in the Residential District of Ancient Nea Paphos, Cyprus, EtudTrav XXXIV, 363-405

Rupp, D.W. 1982: Kourion City: The Eustolios Complex - Area VI, [in:] Wylde Swiny, H. (Ed.), An archaeological guide to the ancient Kourion area and the Akrotiri Peninsula, Nicosia, 132-139

Segal, A., Młynarczyk, J., Burdajewicz, M., Schuler, M., Eisenberg, M. 2007: HipposSussita. Eighth Season of Excavations (July 2007), Haifa

Tell Abu Sarbut: https://tellabusarbut.wordpress.com/renewed-excavations/ (accessed February 28, 2021) 
Trümper, M. 2020: Logistics of Building Processes: The Stabian Baths in Pompeii, [in:] Heinzelmann, M., Recko, C. (Eds), Quantifying Ancient Building Economy: Panel 3.24. Archaeology and Economy in the Ancient World - Proceedings of the 19th International Congress of Classical Archaeology, Cologne/Bonn 2018, Heidelberg, 5-18

Uytterhoeven, I. 2011: Bathing in a 'Western Style'. Private Bath Complexes in Roman and Late Antique Asia Minor, IstMitt 61, 287-346

Uytterhoeven, I. 2020: Following 'Western' Fashion Trends. The Impact of 'Italian' Elements on Private Housing in Roman Imperial Asia Minor, [in:] Lohner-Urban, U., Quatember, U. (Eds), Zwischen Bruch und Kontinuität. Architektur in Kleinasien am Übergang vom Hellenismus zur römischen Kaiserzeit, Byzas 25, 453-471

Wallace-Hadrill, A. 1994: Houses and society in Pompeii and Herculaneum, Princeton Yegül, F. 1992: Baths and Bathing in Classical Antiquity, New York-Cambridge, Mass. Yegül, F. 2010: Bathing in the Roman world, Cambridge 


\section{ÉTUDES et TRAVAUX XXXIV / 2021}
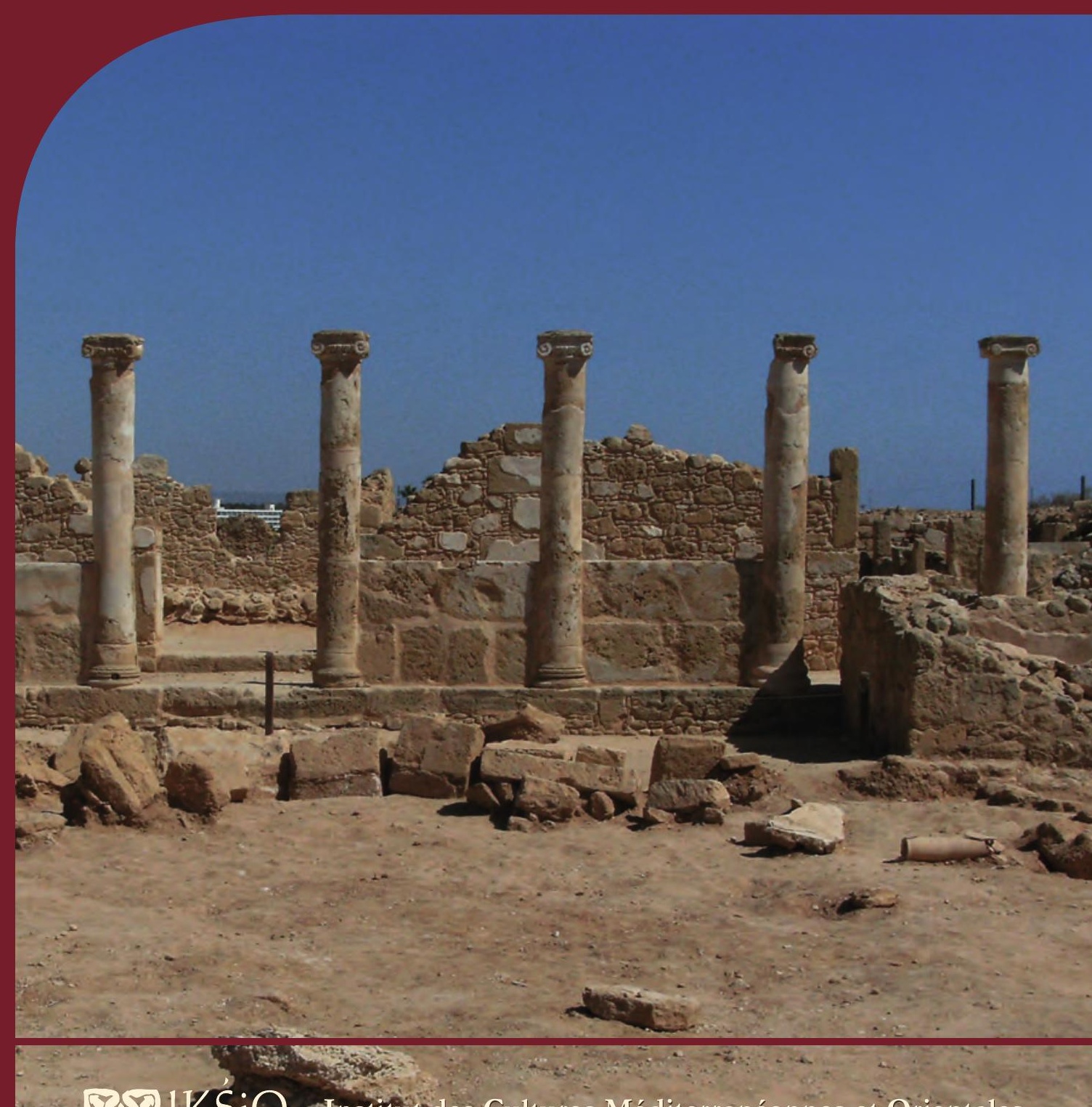

W $92 \mathrm{HKSiO}$ Institut des Cultures Méditerranéennes et Orientales

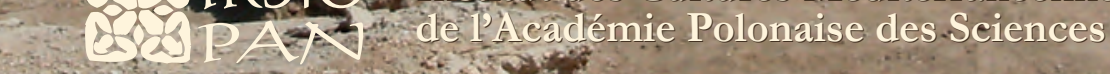

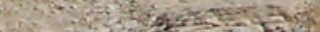

Q 
COMITÉ DE RÉDACTION SCIENTIFIQUE

Maciej Makowski - rédacteur en chef

Jadwiga Iwaszczuk - rédacteur

Katarzyna Kapiec - secrétaire de la rédaction

Henryk Meyza - rédacteur thématique du volume

CONSEIL SCIENTIFIQUE DU JOURNAL

M. Kobusiewicz (IAE PAN, Warszawa)

E. Laskowska-Kusztal (IMOC PAS, Warszawa)

D. Michaelides (University of Cyprus, Nicosia)

J.Ch. Moretti (IRAA-MOM, Université de Lyon 2/CNRS)

D. Raue (Ägyptisches Museum der Universität Leipzig)

P. Reynolds (ICREA, España)

D. Welsby (British Museum, London)

COMITÉ SCIENTIFIQUE DE LECTURE

la liste des membres du comité est accessible en ligne sur

http://www.etudesettravaux.iksiopan.pl

RÉDACTION TECHNIQUE

Marta Kaczanowicz

REVUE DES TEXTES EN ANGLAIS

Jo Harper 
ÉTUDES et TRAVAUX XXXIV 
INSTYTUT KULTUR ŚRÓDZIEMNOMORSKICH I ORIENTALNYCH POLSKIEJ AKADEMII NAUK

\title{
STUDIA i PRACE
}

\section{XXXIV}

\author{
GoIKSiO \\ QSO PAN \\ WARSZAWA \\ 2021
}


INSTITUT DES CULTURES MÉDITERRANÉENNES ET ORIENTALES DE L’ACADÉMIE POLONAISE DES SCIENCES

\section{ÉTUDES et TRAVAUX}

XXXIV

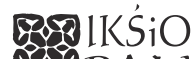

EOSPAN

VARSOVIE

2021 
Publication scientifique financée dans le cadre du programme du Ministre de la Science et de l’Éducation Supérieure

« Programme National de Développement de l’Humanistique » pour les années 2016-2021 (projet no 3bH 150099 83)

\title{
(1) NARODOWY PROGRAM ROZWOJU HUMANISTYKI
}

\author{
Copyright $(C)$ \\ Instytut Kultur Śródziemnomorskich i Orientalnych PAN \\ et les Auteurs \\ Warszawa 2021
}

ISSN 2084-6762

(jusqu'en 2011 : 0079-3566)

e-ISSN 2449-9579
Version première en papier, imprimée en Pologne - 150 copies
Version électronique accessible sur
http://www.etudesettravaux.iksiopan.pl

Édition: Polskie Towarzystwo Historyczne et Wydawnictwo Neriton, Warszawa

Conception générale de la couverture : J. Iwaszczuk

Photographie de couverture : Phot. A. Brzozowska-Jawornicka

(Le portique ionique est, péristyle de la Maison « hellénistique », Nea Paphos) 


\section{Table des matières}

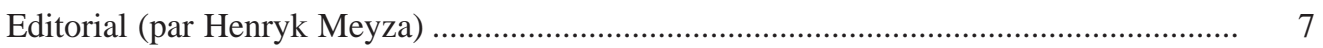

Marta BaJTLER

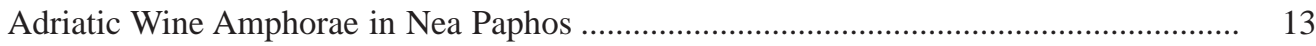

Claire Balandier, Jolanta MlynarczyK

The Temple and Its Surroundings on Fabrika Hill, Paphos: Preliminary Results

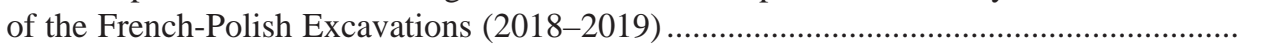

Grażyna BĄKowska-Czerner, Rafal CzERner

The Shell Motif in the Culture and Architecture of the Ancient Town of Marina el-Alamein in Egyp

AleKsandra BrzozowsKa-JaWornicKa

'Hellenistic' House in Nea Paphos, Cyprus - A First Summary of Its Architecture.

AleKsandra BrzozowsKa-JaWORnicKA, AnNa KuBICKA-SowińsKa

In Search of the Module in the Architectural Design of the 'Hellenistic'

House in Nea Paphos, Cyprus

RoKsana HaJduga

Kushite Stamp Impressions from Selib 2, Sudan

ERSIN HusSEIN

Mapping Metal Rich Roman Cyprus: The Case for Object-Centred Approaches

BARBARA LICHOCKA

Villa of Theseus at Nea Paphos (Cyprus). Fourth-Early Fifth Century Numismatic

Evidence for Architectural Transformations and Seismic Events

VASiliki Lysandrou, Demetrios Michaelides

Wall Paintings in Ancient Cyprus: The Hellenistic and Roman Tombs of Paphos

and Its Region

ADAM ŁAJTAR

A Weight of Seleucia in Pieria in Nea Paphos

Diana MroczeK

Ancient Portrait Busts of Marcus Aurelius in the National Museum in Poznań 
Brandon R. Olson, R. Scott Moore, Thomas Landvatter, Justin Stephens

Pyla-Vigla: A Case Study Assessing the Imperial Strategies of the Hellenistic

Diadochoi in Cyprus

Patrizio Pensabene, Eleonora Gasparini

Colonnaded Hall in Kourion: How the Oecus Corinthius Was Interpreted in the Roman

Houses of Cyprus

Monika Rekowska, Demetrios Michaelides, Skevi Christodoulou, JAKUB KANISZEWSKI

Adopting Roman Habits - The Baths in the House of Orpheus in Nea Paphos

as a 'Troublesome' Case Study?

MARCIN M. ROMANIUK

Terracotta Pipelines at Maloutena: Remarks on the Water System in the

Residential District of Ancient Nea Paphos, Cyprus

363

ABRÉVIATIONS

407 